ISSN (print) 0867-2008 / ISSN (online) 2391-75 I2

DOI: http://dx.doi.org/10.12775/OM.2019.009

PRZemyseaW WASZaK*

Katedra Historii Sztuki i Kultury

Wydział Nauk Historycznych

Uniwersytet Mikołaja Kopernika w Toruniu

ul. Władysława Bojarskiego 1

PL-87100 Toruń

Poland

pwaszak@umk.pl

\title{
ARTISTIC LANDSCAPE OF THE FORMER STATE OF THE TEUTONIC ORDER IN PRUSSIA DEFINED BY THE GOTHIC CRUCIFIXES**
}

\section{KEYWORDS}

art; art history; the Middle Ages; military orders; Teutonic Order; Gothic; sculpture; shrine Madonna

\begin{abstract}
The aim of this article is to show a broad artistic panorama of Gothic sculpture of the Teutonic Order State in Prussia. It takes into consideration a few characteristic iconographical types like shrine Madonna and the Beautiful Madonna. But it points out that the numerously preserved woodcarved crucifixes shape the picture of three-dimensional figurative arts of the said state in the eyes of academics and audience. A synthetic review of written sources and scientific approaches was presented, as well as a methodology. Various academic views on one crucifix were shown. Artistic influences and exchange as part of the art of Baltic coast, Central and Western Europe were emphasized. Unpublished, archival photographs were presented and analysed. They show six crucifixes, up to now not known from illustrations.
\end{abstract}

* ORCID: https://orcid.org/o000-0002-3235-9793

** This article is an expanded and annotated version of my paper presented on the 20 th September 2017 at the 8th Forum of Young Researchers of the Military Orders within the Framework of the i 9 th Conference Ordines Militares. Colloquia Torunensia Historica. In preparing this article a research grant no. 2926-NH from the Faculty of History at the Nicolaus Copernicus University in Torun and a fellowship at the Herder Institute for Historical Research on East Central Europe - Institute of the Leibniz Association in Marburg, 20 I 8 were helpful. I would kindly like to thank the Herder Institute for permission to use archival photographs. 


\section{SCOPE, METHODOLOGY, SOURCES}

The aim of this article is an approach to present and define the artistic landscape of the former Teutonic Order State. Statements are explained with the use of examples of woodcarved crucifixes dated to the i 4 th century and the first half of the i 5 th century. These works of art contribute to better understanding of the art of the area. The analyses concentrate on one iconographical type, and on sculptures created with the same technique. There are quoted other types of Gothic sculptures considered to be characteristic for this region. I would like to prove, that the Gothic crucifixes are these works of art, from the angle of which the Gothic fine arts from the territory of the former Teutonic Order State are perceived. Many Prussian crucifixes are widely known and often mentioned. The discussion focuses its attention on my recent archival discoveries of 6 crucifixes whose photographs have not been published so far.

The methodologies used in the article are: geography of art and stylistic and iconographical, comparative analyses. Especially a few publications on method by George Kubler should be named. ${ }^{1}$ On his approach to study the works of art see my article. ${ }^{2}$ Both the content of the literary works, the ideas and the sculptures, their stylistic and typological characteristic features can be perceived similarly to the growing, developing and changing sequences of archaeological, material objects. ${ }^{3}$ I still find useful in practice the way of thinking on art and ideas which Kubler presented in $1962^{4}$ and elaborated in his later articles. This methodology was used by Zofia Białłowicz-Krygierowa in her analysis of a large group of objects belonging to the style of the Gothic, woodcarved Madonnas on lions. ${ }^{5}$ The basis for the concept of artistic landscape is an article on the geography of art of the territory of the Teutonic Order State by Marian Kutzner. ${ }^{6}$

I George Kubler, Studies in Ancient American and European Art: The Collected Essays of George Kubler, ed. Thomas F. Reese (New Haven-London: Yale University Press, I 98 5), 378-430.

2 Przemysław Waszak, "Rozwojowe ciągi formalno-ideowe w ramach konstrukcji czasu artystycznego George'a Kublera," Sztuka i Kultura 5 (2017) (in print).

3 Sergiusz Michalski, Einführung in die Kunstgeschichte (Darmstadt: Wissenschaftliche Buchgesellschaft, 20I6), 62, 63 compares the scientific treatement of the archaeological sequences to the way of thinking on art in the methodological book of George Kubler.

4 New edition: George Kubler, The shape of time: remarks on the history of things (New Haven-London: Yale University Press, 2008).

s Zofia Białlowicz-Krygierowa, Studia nad snycerstwem XIV wieku w Polsce, vol. I, Poczatki ślaskiej tradycji ottarza szafowego (Warszawa-Poznań: Państwowe Wydawnictwo Naukowe, I 98 I).

6 Marian Kutzner, “Ziemia pruska i charakterystyka jej sztuki w okresie średniowiecza," Teka Komisji Historii Sztuki I (2005): 28-46. 
Artistic oeuvre of the Teutonic Order State in Prussia is extensive and consists of many outstanding works of art. We take into consideration first of all Gothic sculptures dated historically prior to the beginning of the Thirteen Years' War. In these times, the gradually expanding territory belonging to the Teutonic Knights was the largest in history. Stylistically the discussed sculptures were created prior to the dark period, from which, also in the Kingdom of Poland fewer sculptures survived. After this period style gravitated towards the late-Gothic style. In the I 4 th century and partly in the first half of the i 5 th century the prosperity of various groups of founders allowed execution or import of numerous works of art of high artistic value. From the discussed epoch and territory survived or is known from literature or photographs no fewer than 77 Gothic, woodcarved crucifixes. It is a large number of works on the scale of Poland, although there are regions with many more known such sculptures. For example, the number of dated only to the I 4 th century crucifixes from the territory of Denmark is around i $10 .^{7}$ Numerous turmoils and wars contributed to the losses of the works of art from the territory which belonged to the state of the Teutonic Knights in Prussia.

The plastic arts of the Teutonic Order State were influenced from the West and the South. The last ones were pointed out particularly by Hans Wentzel who named Austria, Silesia and Bohemia. ${ }^{8}$ Direct imports were also possible. The Teutonic Order State did not only import ready sculptures and artistic solutions, was not only simply artistically colonized.?

Knowledge of some of the Gothic crucifixes is confirmed by mediaeval sources. For instance, the testament of Nicolaus Wulsack, the parish priest of the St. Nicolaus Church in Elbing (today: Elbląg). There is mentioned a foundation of a monumental crucifix ( I 400-I 4 I 4$)^{10}$, one of the most important artistic achievements.

7 Susanne Wennigsted-Torgard, "Kruzifixe des i 4. Jahrhunderts auf Lolland-Falster und in Nordjütland," in Figur und Raum: mittelalteriche Holzbildwerke im historischen und kunstgeographischen Kontext, ed. Uwe Albrecht and Jan von Bonsdorff, with Annette Henning (Berlin: Dietrich Reimer, I 994), 70, 80 and illus. I.

8 Hans Wentzel, review of Die mittelalterliche Bildhauerkunst im Deutschordensland Preußen. Die Bildwerke bis zur Mitte des Is. Jhdts., Berlin, by Karl Heinz Clasen, Zeitschrift des Vereins für Lübeckische Geschichte und Altertumskunde 30, no. 2 (1940): 389.

9 Discussion on the problems and terms, among others, "Kolonisationskunt", "Randzone" in relation to medieval art in the Central-Eastern Europe was elaborated by Marian Kutzner, "Sztuka a kolonizacja niemiecka na wschód od Odry," in Niemcy - Polska w Średniowieczu: materiaty z konferencji naukowej zorganizowanej przez Instytut Historii UAM w dniach I4-I6 XI I983 roku, ed. Jerzy Strzelczyk (Poznań: Uniwersytet im. Adama Mickiewicza, I 986), 337-353.

10 Das Elbinger Stadtbuch, vol. 2, ${ }_{3} \sigma_{I}-I_{4} I 8$, ed. Hans W. Hoppe, Zeitschrift für die Geschichte und Altertumskunde Ermlands 5 (Münster: Historischer Verein für Ermland, I 986), 283, entry 23 I 8 ( 14 I 4 year). 
The source mentions literally a big cross (mit dem grosen cruce) but lists also the rest of the monuments of this parish church. For example, dated to the beginning of the I 5 th century statues of the Apostles.

Thanks to the written sources there are known also non-surviving crucifixes. The crucifix is the most important, almost compulsory part of the church equipment. For instance, there is a mention of a large, wooden figure of Lord (lignum Domini maius). The statue was most probably donated towards the end of the I 3 th century by, according to the source, pious knight (miles devotus et precipuus), benefactor and friend of the church in Garnsee (Gardeja). Dietrich Stange was a local lord. The source is the book of the dead from the Cistercian monastery in Pelplin. The date of the foundation is made more credible as we know that in I 285 the knight donated Garnsee (Gardeja) to the monastery in Pelplin ${ }^{11}$, so only I I years after the convent arrived in Pelplin. The crucifix could rather be imported.

The sources contain laconic statements from the point of view of contemporary researchers and art viewers. The sources first of all point at a pious foundation of cult objects. Also, in modern times, the mentions had very brief character. The crucifix from the St. Mary Church in Gdańsk (Danzig, ca I 425) was described towards the end of the 17 th and in the first half of the 18 th century in the following short way: on the altar there is a middle-sized crucifix (Auffm Altar ist von einer mittelmeßigen Grösse ein Crucifix). ${ }^{12}$

Different situation is with publications. Since the beginning of the I 9 th century there is a growing development of the literature describing antiquities, academic research and the literary output. At the turn of the 20 th century many inventories of historic monuments were published. The works of art are mentioned there especially when they were exceptional, had original shape or different approach to the established iconography of a known topic. It is worth to notice that short statements can be found not only in sources but also in later catalogues and inventories of historic monuments published in the 19 th, 20 th and 2 ist century. From around the 1937 to the 1964 a few monumental monographs of Gothic sculpture of the

${ }_{1}$ Liber Mortuorum Monasterii Pelplinensis ordinis-cisterciensis, ed. Wojciech Kętrzyński, in Monumenta Poloniae Historica / Pomniki dziejowe Polski, vol. 4, ed. Lwowska Komisya Historycznej Akademii Umiejętności (Lwów: Druk. Zakład Narodowy im. Ossolińskich, i 884), 67; Mario Glauert, "Kirchen, Klöster und Spitäler zwischen Marienwerder und Rosenberg im Mittelalter: Ein Beitrag zur Sakraltopographie und Prosopographie des Niederklerus im Deutschordensland Preußen," Beiträge zur Geschichte Westpreußens 20/2 I (2006): 98.

12 Valentin Schlieff, Der S. Marien Pfarrkirchen in Dantzig inwendiger Abriss beschrieben von Gregorio Frischen [...] Anno 1731. abgeschrieben und hin wieder verbessert und vermehret, Biblioteka Gdańska Polskiej Akademii Nauk, Ms. 488, p. I 6. It is a copy of an earlier manuscript written in $1694-1698$. 
particular regions of the Baltic Sea area were published e.g.: connected to the circle of Lubeck, the Teutonic Order State in Prussia, Estonia and Finland. ${ }^{13}$

\section{IMPORTANCE AND CHARACTERISTIC OF OTHER ICONOGRAPHICAL TYPES}

It is worth noting that only one surviving crucifix is known without any doubt to be sculpted for the Teutonic Knights. It is a heavily damaged object from the castle church in Marienburg (Malbork, I330-1 344, nowadays Castle Museum). ${ }^{14}$ The crucifix from Golub-Dobrzyń (Gollub, i 400-1 410) because of its high artistic value, monumentality, displaying in a much later, classicistic church and altarpiece might come from the castle chapel in the castle of the Teutonic Knights in Gollub. is

Among the sculptures which, thanks to their iconographic or stylistic features are considered to be characteristic for the art of the Teutonic Order State we can name Beautiful Madonnas, shrine Madonnas and Madonnas on Lions.

It should be noted that there are only known two Beautiful Madonnas from Prussia: the one from Torun (Thorn, ca I 390), which is among the sculptures of its type the most emblematic one. The second one is later, somewhat differently characterised by the sculptor and painter Madonna from Gdańsk (Danzig, ca I 420). But it is not the lost Beautiful Madonna which is considered to be the most important symbol of Thorn (Toruń). The work of art filled with meanings, often displayed and copied is the Gothic crucifix on the Tree of Life from the St. James Church in Torun (Thorn, around I 360-1390).

The shrine Madonnas in Prussia are known from Lubieszewo Tczewskie (Liebschau, ca I 400) and Klonówka (Klonowken, ca I 400) which are on display in the Diocesan Museum in Pelplin. One shrine Madonna from castle chapel in Roggenhausen (today: Rogóźno bei Grudziądz), around I395) is displayed in the

13 Hans Wentzel, Lübecker Plastik bis zur Mitte des 14. Jahrhunderts (Berlin: Deutscher Verein für Kunstwissenschaft, 1938); Karl Heinz Clasen, Die mittelalterliche Bildhauerkunst im Deutschordensland Preussen. Die Bildwerke bis zur Mitte des Is. Jahrhundert, vol. I-2 (Berlin: Deutscher Verein für Kunstwissenschaft, 1939); Sten Karling, Medeltida träskulptur i Estland (Stockholm: Kungl. Vitterhets Historie och Antikvitets Akademien, 1946); Carl Axel Nordman, Medeltida skulptur i Finland (Helsinki: Finska fornminnesföreningen, I964); A little later: Villem Raam, Gooti puuskultur Eestis (Tallinn: Kirjastus “Kunst”, 1976).

14 Lately: Anna Błażejewska, Rzeźba w Prusach Krzyżackich do potowy XIV wieku: źródta stylu (Toruń: Wydawnictwo Naukowe Uniwersytetu Mikołaja Kopernika, 20 I 2), I63-172, I74-175.

is Such probable conjectures appear repeatedly in literature, for example: Tadeusz Chrzanowski and Marian Kornecki, "Nieznane rzeźby gotyckie kręgu pomorskiego," Rocznik Historii Sztuki 8 (1970): $32 \mathrm{I}-322$. 
Germanisches Nationalmuseum in Nuremberg. One is known from the Musée de Cluny in Paris (ca I 400), other from Sejny (ca I 4 I O), Elbląg (Elbing, ca I 400) and from other places in different countries. ${ }^{16}$ These are free-standing, moveable sculptures which are not connected to architecture nor, presently, with an altarpiece. They are also named "the winged altar Madonnas" ${ }^{17}$. Concerning such three-dimensional or nearly three-dimensional sculptures frequently on display in museum collections there always can be doubts of their place of origin and location in the church. Although crucifixes often remain in churches as cult objects. Origin of many rather small devotional images cannot be determined precisely.

Also, the Madonnas on lions are not only characteristic of the Teutonic Order State because they appear among others in the territory of Silesia, Greater Poland, Kuyavia $^{18}$ and could originate in Bohemia. The last point is under debate. ${ }^{19}$

Another iconographical type discernible in the Gothic art along the Baltic coast: Madonna holding the newly born infant Jesus on a bed from a cloister in Askeby was compared early to the only typologically analogous sculpture in Hela (Hel, ca I 350$)^{20}$, which is currently on display in the National Museum in Gdańsk. Similar is also a sculpture from Estonian Vormsi (Ormsö, ca I 405-1 4 I O). ${ }^{21}$ This exemplifies, that there are other iconographical types which are copied or have close counterparts along the Baltic coast.

16 Roman Ciecholewski, "Problematyka badawcza pomorskich Madonn szafkowych," Studia Pelplińskie 8 (1977): I29, I 3 I; Frank Matthias Kammel, "Andachtsbild und Formvielfalt: Skulptur," in Mittelalter: Kunst und Kultur von der Spätantike bis zum I s. Jahrhundert, ed. Jutta Zander-Seidel (Nürnberg: Germanisches Nationalmuseum, 2007), 280-282, illus. 25 I, 264; Gudrun Radler, Die Schreinmadonna "vierge ouvrante": von den bernhardinischen Anfängen bis zur Frauenmystik im Deutschordensland; mit beschreibendem Katalog (Frankfurt/Main: Kunstgeschichtliches Institut der Johann Wolfgang Goethe-Universität, I 990), passim.

17 Lennart Karlsson, “Träskulpturen," in Den gotiska konsten, Signums svenska konsthistoria, vol. 4, ed. Jan-Erik Augustsson (Lund: Bokförlaget Signum, I 996), 264.

18 Białłowicz-Krygierowa, Studia, passim, map.

19 Romuald Kaczmarek, "Neue Überlegungen zu den schlesischen Löwenmadonnen: ihr Ursprung und stilistisch-formale Parallelentwicklungen in der Steinplastik," in Madony na lvu a měkký styl treté čtvrtiny 14. století: príspèvky z mezinárodního symposia [Arcidiecézní Muzeum Olomouc, Ig. bezen 2014], ed. Jana Hrbáčová and Pavol Cerný (Olomouc: Muzeum umění, $2014), 33,35,36$.

20 Carl R. Af Ugglas, “Sverige - Danzig eller Sverige - Köln - eller...?” Tidskrift för Konstvetenskap 25 (1944): 37, 38, fig. 20, 2 I.

${ }_{21}$ Karling, Medeltida träskulptur, fig. 56, 57, 59. 


\section{ART WHICH IS CONSTANTLY CROSSING THE BORDERS}

The following facts should be listed. Some Prussian sculptures are similar iconographically, stylistically and regarding their shape to Swedish sculptures. There is a particularly large number of Gothic sculptures preserved in Sweden. Noteworthy example is the island Gotland with around 33 sculpted and painted, dated to the i 4 th century altarpieces, which mainly survived in a good condition. ${ }^{22} \mathrm{~A}$ few Swedish crucifixes, due to their similarities, can be placed under a question mark as works originated in Danzig (Gdańsk). First of all, the crucifix from Fårentuna (around I 430) should be named. It has been compared to the crucifix from the St. Mary Church in Danzig (Gdańsk) since around $1940^{23}$ up to the present times. ${ }^{24}$ Already in 1940 Wentzel was convinced that some of the sculptures of the Teutonic Order State were imported to Sweden. ${ }^{25}$ It seems that the art of mediaeval Prussia was influential, and both preserved and admired through the ages in later epochs. But also, other Swedish crucifixes are similar to Prussian ones like those from Vadstena and Askeby, dated respectively to the first (ca I 430) and the second half of the I 5 th century (ca I 460-I 470). ${ }^{26}$ The crucifix from Gdańsk (Danzig) itself influenced a few other works of art, for example the crucifix from Stawno (Schlawe, around I 430) in West Pomerania, on display in the National Museum in Szczecin (Stettin). Gdańsk's influence on Finnish sculpture was considered, too. ${ }^{27}$

22 Peter Tångeberg, Retabel und Altarschreine des 14. Jahrhunderts: schwedische Altarausstattungen in ibrem europäischen Kontext (Stockholm: Kungl. Vitterhets Historie och Antikvitets Akademien, 2005), 7; id., "Retables and winged altarpieces from the fourteenth century: Swedish altar decorations in their European context," in The altar and its environment: II50$-I 400$, ed. Justin E. A. Kroesen and Victor Michael Schmidt (Turnhout: Brepols, 2009), 223.

23 Rune Norberg, "Helga Lekamensbilden i Vadstena och triumfkrucifixet i Söderköping," Birgittastiftelsen årsberättelse I ( I 94I): 25, after Peter Tångeberg, Das "Schöne Kruzifix" in Vadstena und Nussbaumbolzskulpturen aus dem Deutschordensland (Stockholm: Almqvist \& Wiksell International, I 993), note 58; Af Ugglas, "Sverige," 3 I, 32, note 64.

24 Peter Tångeberg, "Künstlerische Verbindungen Schwedens im Mittelalter. Eine Übersicht," in Niederländische Kunstexporte nach Nord- und Ostmitteleuropa vom I4. bis I6. Jahrhundert: Forschungen zu ibren Anfängen, zur Rolle höfischer Auftraggeber, der Künstler und ibrer Werkstattbetriebe, ed. Jiří Fajt and Markus Hörsch (Ostfildern: Jan Thorbecke Verlag, 20 I 4), 73.

25 Wentzel, review of Die mittelalterliche Bildhauerkunst, 390.

26 New analysis of the crucifix: Gerhard Lutz, "Das Kruzifix von Askeby und die altniederländische Skulptur," in "Nicht die Bibliothek, sondern das Auge": westeuropäische Skulptur und Malerei an der Wende zur Neuzeit; Beiträge zu Ehren von Hartmut Krohm, ed. Tobias Kunz (Petersberg: Imhof, 2008), I I I - I 9 .

27 Carl Axel Nordman, "Eigenes und Fremdes in der mittelalterlichen Kunst Finnlands," in Aspekte zur Kunstgeschichte von Mittelalter und Neuzeit. Karl Heinz Clasen zum 75. Geburtstag, ed. Hans Müller and Gudrun Hahn (Weimar: Böhlau, I 975), 244-245. 
These facts, comparisons of very similar works of art indicate, that the artistic forms were exported towards the north of the Baltic Sea. It is worth to note, that the area of the lowlands of the Baltic Sea and the North Sea, place of Hanseatic influences is somewhat similar to the earlier, dated to the ancient, late-ancient and the early Christian times and evidently more consolidated cultural community of the Mediterranean Sea. ${ }^{28}$ Somewhat similar statements are present in many scientific works. Both regions of Europe were of special interest to the academics. The differences and various possibilities in treatment of the culture of the Mediterranean Sea region and the Baltic Sea region are pointed out by Stanisław Roszak in the context of "the places of memories". ${ }^{29}$ Crucial point is that the Baltic Sea area which was singled out as a separate historical region also by Fernand Braudel had been since the 14 th century a prolific and vast open artistic region..$^{30}$ Various artistic works created in different techniques prove connections between East and West, North and South of the Baltic Sea. The known artworks define the place of the Teutonic Order State in the I 4 th and I 5 th century artistic, sculptural, European output as an important one.

\section{ACADEMIC VIEWS ON THE CRUCIFIXES}

Picture of the Prussian crucifixes shaped in academic research is far from uniformity. The works of art do not form apart from a few examples, especially concentrated around the works in Torun (Thorn) and Gdańsk (Danzig) any distinctive, explicit analogies, groups of fortunately survived, similar objects. In Torun (Thorn) no fewer than 5 Gothic crucifixes are preserved. The Prussian crucifixes constitute a heterogeneous group of objects, but on a good or very good artistic standard. View on their artistic genesis cannot be described as only polarized. There are rather several views concerning only one crucifix. The hypotheses of artistic genesis can in my view explain to the reader various aspects of artistic forms using different analogies, parts of varied, separate, changing networks of artistic and cultural connections. Already before the second world war and at its beginning influences from the West and from the South (from Bohemia) were pointed

28 Philippe Dollinger, Dzieje Hanzy: (XII-XVII wiek), trans. Vera Soczewińska (Gdańsk: Wydawnictwo Morskie, i 975), i 9.

29 Stanisław Roszak, "Morze jako miejsce pamięci w edukacji," in Battyk jako miejsce pamięci w edukacji historycznej, ed. Danuta Konieczka-Śliwińska, Małgorzata Machałek, and Stanisław Roszak (Szczecin-Warszawa: Polskie Towarzystwo Historyczne, 20 I 7 ), i I - I 2.

30 Tadeusz J. Żuchowski, "Niezwykłe spotkania. O wspólnocie artystycznej basenu Morza Bałtyckiego," Materiaty Zachodniopomorskie n.s. I, Nr. 2 (2004): 55. 
out. Suggestions of Italian, Bohemian, Flemish influences and coming from different parts of Germany are put forward concerning only one crucifix since the early I 9 th century to the present day. The same hypotheses are repeated in a slightly different context. An example of this research impasse caused by the multiplicity of views is the Gothic crucifix from the St. Mary Church in Gdańsk (Danzig). Therefore, I made decision not to analyse in my monograph on the subject of this outstanding crucifix once again stylistic origin of this crucifix, but its extensive artistic, cultural and literary phenomenon.${ }^{31}$ Due to the scale of academic reception of Prussian crucifixes I decided to describe every crucifix and to present extensively the academic discussion on every of the crucifixes in my doctoral dissertation. I resolved to do so, because already first reviews of Karl Heinz Clasen's valuable book pointed on the one side a large number of mentioned sculptures (around 65 I catalogue entries) and on the other hand the entries and the catalogue were considered as too concise. ${ }^{32}$

For example, there are many hypotheses concerning the crucifix on the Tree of Life from the Dominican Church of St. Nicholas in Torun (Thorn). It is presently displayed in the parish St. James Church. Concerning its artistic genesis, the following examples were suggested: Saxony (South-East Germany), influence of the Master of Beautiful Madonnas, influences from the West. Its sculptor could be the Master of Torun (Thorn) Crucifixes which came from the West and was influenced by the Beautiful Madonnas style and by the style of the Madonnas on lions, as well as the influences from the North or South by the way of Bohemia were discernible, in another view: influences from the Rhineland. The sculptor was also thought to learn his craft in Thuringia and came to Torun via Austria, Bohemia, Silesia and South Germany. The analogy to the earlier crucifix from the castle church in Malbork (Marienburg) was quoted. The analogy to the Christ in the Tomb from the Franciscan St. Mary Church in Torun (Thorn, nowadays the District Museum in Toruń) was suggested, too. An import from Westphalia or Cologne was suggested, too. ${ }^{33}$

${ }^{31}$ Przemysław Waszak, Krucyfiks z Kaplicy Jedenastu Tysięcy Dziewic w Bazylice Mariackiej $w$ Gdańsku. Jego znaczenie i recepcja (Toruń: Wydawnictwo Naukowe Uniwersytetu Mikołaja Kopernika, 2016), 9.

32 Wentzel, review of Die mittelalterliche Bildhauerkunst, 388, 392.

33 State of research: Przemysław Waszak, "Snycerskie krucyfiksy na obszarze Państwa Krzyżackiego w XIV i pierwszej połowie XV wieku," vol. I (PhD Diss., Nicolaus Copernicus University, 20I2), 37, 38, 424-50 (cat. no. 69), in preparation to print; Przemysław Waszak, "Krucyfiks mistyczny na Drzewie Życia w kościele św. Jakuba, pochodzący z kościoła dominikanów (św. Mikołaja) w Toruniu," (MA thesis, Nicolaus Copernicus University, 2006). 
Searching for the analogies to this work of art and trying to place its stylistic elements in the sequences of the development of the I 4th century art in Western Europe I pointed out above all the elements forming the mass of the crucifix from Lassnitz bei Murau in Austria, Styria which originates from the Benedictine collegiate church in Sankt Lambrecht. Important are also the motifs of the artistic shape of the perizoma of the Dominican crucifix from Friesach. Both crucifixes are called Styrian Mystical Crucifixes, also a sort of a sequence of several different, but connected works of art. The similar stylistic features which I found in the Styrian crucifix from Lassnitz were named by Clasen in 1939 in reference to the Torun crucifix. Clasen attached importance to his stylistic analyses. He used such descriptions as the Master of Beautiful Madonnas. They were criticised, but they may still be useful as helpful, categorising terms although they rather do not define exact artists' personalities active in the Middle Ages. The perizoma of the crucifix from Torun, dated after the 1360 inclined to search other genesis of its painterly stylistic of folds of drapery. I quoted some examples of Giotto's frescoes, especially from the Capella Bardi in Florence, dated to the 1325-1 328 and these motifs could come to Prussia via Silesia and Bohemia. ${ }^{34}$ This is my position concerning the complex artistic origin of the most outstanding Prussian crucifix. I articulated it for the first time in master's thesis in 2006. It comprised the analysis of stylistic origin (sequences of artistic development), iconography, mystical context and history of the crucifix.

\section{UNPUBLISHED CRUCIFIXES}

In the following part I would like to demonstrate an important addition to the artworks, often masterpieces analysed and interpreted in the above part of the article. The crucifixes and other sculptures named in the article so far are among the better-known ones and the more often published ones from the Teutonic Order State in Prussia. But there are still Gothic crucifixes which have not been published until the present time. They are not known or there are only short mentions about them not accompanied by illustrations. The Herder Institute in Marburg houses an extensive collection of an art historian and mediaevalist Karl Heinz Clasen. It comprises invaluable pre-war photographs and is simply called "Sammlung Clasen". All other mentioned contextual crucifixes were analysed, illustrated and catalogued in my dissertation.

34 Przemysław Waszak, "Krucyfiks na Drzewie Życia z dominikańskiego kościoła św. Mikołaja w Toruniu - nowe spojrzenie," Sztuka i Kultura I (2013): 25-28. 
I would like to publish for the first time archival photos discovered during my research conducted in the archives of the Herder Institute. The crucifixes published in this article are up to now not known from photographs. The first one comes from the priest's house in Rychliki (Reichenbach o. Preuss. Holland, height $62 \mathrm{~cm}$, photo I). Clasen saw in it a work of art of simplified stylistic and formal features. For him it had even folk character. According to Strauss it can be compared in the terms of workshop features with the crucifix from the former Municipal Museum in Elbląg (Elbing, I 430-I 450, which came from the St. George church). Strauss named a few crucifixes connected with this non-existent Elbląg (Elbing) crucifix. What is more he pointed out that the church in Rychliki (Reichenbach) enjoyed the patronage of the town council of Elbląg (Elbing). Therefore, it may be supposed that the crucifix from Rychliki (Reichenbach) was executed in a workshop from Elbląg (Elbing). ${ }^{35}$ The similarities between the nearly 3 times larger crucifix from Elbląg (Elbing) are evident when comparing perizoma and chest. Different are particularly the hair and physiognomy. The crucifix from Rychliki (Reichenbach) can be described as a work of a follower of the Elblag (Elbing) crucifix, coming from its workshop. The later crucifix from Rychliki (Reichenbach) is not much simplified in comparison to its model but less massive in proportions. It lacks the monumentality of the silhouette and fine details of head and hair of its prototype. In both cases especially the richly formed shape of the crosses is similar, nearly identical in general and in detail. The crucifix in Rychliki (Reichenbach) is nailed to a cross in the form of a tree of life with symbols of the four Evangelists in rounded medallions at each end of the horizontal and vertical beam of the cross. The highest medallion was not preserved. The sprouts (not snags) of the living Tree of Life are symbolized by identical semicircles attached numerously to both sides of each beam of the cross. There are known seven similar richly shaped crosses from the Teutonic Order State. According to Clasen the cross from Rychliki (Reichenbach) is called in German Scheibenkreuz (a cross with wooden discus-like shapes).

The second is the large crucifix which comes probably from a parish church in Lidzbark Warmiński (Heilsberg, later it was housed in the local castle museum,

35 Waszak, "Snycerskie krucyfiksy," I: 397-398 (cat. no 62); Michael Antoni, Debio-Handbuch der Kunstdenkmäler West- und Ostpreußen: die ehemaligen Provinzen West- und Ostpreußen (Deutschordensland Preußen) mit Bütower und Lauenburger Land (München-Berlin: Deutscher Kunstverlag, 1993), 524; Clasen, Die mittelalterliche Bildhauerkunst, I: 249, 345 (cat. no. 524); Georg Dehio and Ernst Gall, Deutschordensland Preußen, Handbuch der deutschen Kunstdenkmäler, with Bernhard Schmid and Grete Tiemann, (München-Berlin: Deutscher Kunstverlag, 1952), I65; Gerhard Strauss, Freiplastik bis 1450 im Gebiet des heutigen Ostpreußen westlich der Passarge: Studie zur Geschichte mittelalterlicher Kunst im Ordensland Preußen (Königsberg: Albertus-Universität, I937), 46, I I 4 (cat. no. 39). 
larger than life-size: height 2 I $5 \mathrm{~cm}$, width I $50 \mathrm{~cm}$, repainted, photo 2). Clasen perceived this work of art as simplification of stylistic motifs and anatomy and dated it before the middle of the 15 th century. ${ }^{36}$ There is a large group of known crucifixes from Ermland (Warmia) and Ostpreussen (Prusy Wschodnie). The larger crucifix from Lidzbark Warmiński (Heilsberg) postdates the lost crucifix from Szymonowo (Gross-Simnau, I 400-I 425 , height I $8 \mathrm{~cm}$ ). The first one has shorter, not so developed perizoma which is hung in a lower position. Nevertheless, the larger crucifix from Lidzbark Warmiński (Heilsberg) has features (anatomy, head, way of hanging on the cross) which allow to compare it to the earlier crucifix from Szymonowo (Gross-Simnau). So, it is not an isolated example without any analogies. Especially its perizoma is typical and may be compared to the loincloth of the crucifix from The Diocesan Museum in Pelplin (coming from Starzyno (Gross-Starzin), around I 425-1450).

Also, the third unpublished crucifix comes from that castle museum in Lidzbark Warmiński (Heilsberg, half life-size, repainted, photo 3). Clasen observed in this work of art a reduction of stylistic and anatomical features and dated it to the middle of the i 5 th century. ${ }^{37}$ Both mentioned crucifixes from Lidzbark Warmiński (Heilsberg) although dated similarly were sculpted in different workshops. The smaller one in my opinion resembles the also colourfully repainted crucifix from the baroque pilgrimage church in Chwalęcin (Stegmannsdorf, smaller than lifesize, ca I 400-I 425) located on the periphery of Ermland (Warmia), not far from Lidzbark Warmiński (Heilsberg). The crucifix in Chwalęcin (Stegmannsdorf) is venerated as miraculous and it was described in legends. Probably therefore it was not transferred to any museum. The crucifix was quoted as an example of forming own Gothic style of the wooden sculpture of the Teutonic Order State. ${ }^{38}$ Among Prussian crucifixes its shape (physiognomy, chest, legs and hands, way of hanging on the cross) is closest to the form of the smaller crucifix from Lidzbark Warmiński (Heilsberg). There are three Gothic crucifixes known from the collections of the pre-war castle museum in Lidzbark Warmiński (Heilsberg) of which up to now

36 Waszak, "Snycerskie krucyfiksy," I: 3 I o, 3 I I (cat. no 34); Clasen, Die mittelalterliche Bildhauerkunst, I: 266, 3 I 9 (cat. no 20 I); Mieczysław Orłowicz, Ilustrowany przewodnik po Mazurach Pruskich i Warmji, Polska Biblioteka Turystyczna, no. 6 (Lwów-Warszawa: Książnica Polska Towarzystwa Nauczycieli Szkół Wyższych, 1923), 224.

37 Waszak, "Snycerskie krucyfiksy," I: 3 I 2 (cat. no. 35); Clasen, Die mittelalterliche Bildhauerkunst, I: 266, 3 I 9 (cat. no. 202).

38 Katalog zabytków sztuki w Polsce. Seria nowa, vol. 2, Województwo elblaskie, fasc. I, Braniewo, Frombork, Orneta i okolice: tekst, ed. Marian Arszyński, Marian Kutzner, Piotr Skubiszewski, and Ewa Struszyńska (Warszawa: Instytut Sztuki Polskiej Akademii Nauk, I 980), XXIV. 
photographs of only one of them were published. ${ }^{39}$ The crucifix from Chwalęcin (Stegmannsdorf) is in my view comparable with the mentioned crucifix from Starzyno (Gross-Starzin) and another crucifix from parish church in Sartowice (Sartowitz). The three sculptures form a distinctive group. The analysed crucifix from Lidzbark Warmiński (Heilsberg) may be added to that group.

The fourth unknown art object is the smaller, at the time of taking the photograph repainted crucifix from the catholic parish church in Miłoradz (Mielenz, ca I 450 , photo 4 ) in the vicinity of Malbork (Marienburg)..$^{\circ}$ It is worth to note that the second woodcarved crucifix - the monumental one from the parish church in Miłoradz (Mielenz) is even quite widely known and its cross was examined dendrochronologically. Thanks to that analysis that crucifix is precisely dated to circa I $398 .{ }^{41}$ The small crucifix from Miłoradz (Mielenz) does not share any distinctive features with the larger and earlier crucifix in that parish church. It is characterised by a slightly inflated chest and flattened, looking like blocks folds of drapery. The form of the short, simplified perizoma suggests later date of execution, towards the middle of the i 5 th century. Some features of physiognomy of the crucifix resemble a small and portable Gothic crucifix from Orneta (Wormditt, I 390-I 4 I 0$)^{42}$ whereas the reduced shape of the perizoma might be compared to a Gothic crucifix from Bartoszyce (Bartenstein, I420-I440, lately in Olsztyn (Allenstein), Muzeum Warmii i Mazur (The Museum of Warmia and Masuria)). ${ }^{43}$

The fifth unpublished work of art is the Gothic crucifix from above the entrance to the earlier St. James's hospital in Torun (Thorn, 4 Szpitalna Street, facing the north side of the choir of the Gothic St. James church, repainted, around lifesize, photo 5). Nowadays it is replaced by an apparently later, half life-sized crucifix of a simplified shape, what can be misleading for researchers and art viewers reading older literature. Also, another Gothic work of art: monumental Christ in the Tomb from Chełmno (Kulm, which has double-functions due to moveable arms

39 Waszak, "Snycerskie krucyfiksy," I: 307-309 (cat. no. 33); id., "Snycerskie krucyfiksy na obszarze Państwa Krzyżackiego w XIV i pierwszej połowie XV wieku,” vol. 2 (PhD Diss., Nicolaus Copernicus University, 20 I 2), illus. I02, I03.

40 Unpublished.

41 Waszak, "Snycerskie krucyfiksy," I: 324-328 (cat. no. 39); id., "Snycerskie krucyfiksy," 2: illus. I I 5-I 22; Tomasz Ważny, "Analiza dendrochronologiczna rzeźby „Chrystus Ukrzyżowany” z kościoła w Miłoradzu (woj. pomorskie), Toruń, I 7.I I.2003," [typescript], in Dokumentacja prac konserwatorskich i restauratorskich, Chrystus Ukrzyżowany (w Mitoradzu), ed. Andrzej Jarmiłko (Toruń 2003), Sztum, Archiwum kościoła św. Anny, [pages not numbered].

42 Waszak, "Snycerskie krucyfiksy," I: $352-355$ (cat. no. 48); id., "Snycerskie krucyfiksy," 2: illus. I 43-I 46.

43 Waszak, “Snycerskie krucyfiksy," I: 342-343 (cat. no. 44); id., "Snycerskie krucyfiksy," 2: illus. I 37,138 . 
and could be used as a crucifix) was exposed outside. Such a place of exposition is naturally harmful for wooden sculptures. ${ }^{44}$ The crucifix from Szpitalna Street was compared by Gwido Chmarzyński to the crucifix from St. Catherine's Church in Gdańsk (Danzig, I 390-1410, nowadays National Museum). On the other hand, Clasen treated the crucifix as a work of art created under the influence of the workshop of the crucifix from the former cathedral in Chelmża (Culmsee). ${ }^{45}$ The similarities to the larger, more than life-size crucifix from the former rood screen in Chełmża (Culmsee, I 400-I 425) are apparent. Especially the physiognomy with half-opened mouth and long beard. The accentuation of death and suffering on the cross is analogous. It is to mention the shape of both ascetic and inflated chest. Also, created with solid, thick links crown of thorns in Chełmża (Culmsee) was repeated in the work of the imitator in the crucifix from Szpitalna Street. The shapes of perizomas although naturally not identical have quite similar arrangement of likewise deep, emphasized folds. In the example of Szpitalna Street the folds became sharper, bigger and even deeper. The follower of the Chetmża (Culmsee) crucifix simplified the above-mentioned features and at the same time made them more prominent. Comparisons show that he clearly modelled the crucifix from Szpitalna Street on the nearby cathedral crucifix.

The sixth presented for the first time work of art is the Gothic crucifix from the parish church in Osice (Wossitz, height of the corpus 7I cm, photo 6) near Gdańsk (Danzig), in which Clasen saw the late influence of the Beautiful Madonnas' style. Other works of art from this church could be sculpted by the same creator. ${ }^{46}$ The crucifix was fixed to the cross in a type of a tree of life of rather later date. It is topographically close to other crucifixes from small places: Niedźwiedzica (Bärwalde, I 425-I 450, height $50 \mathrm{~cm}$ ), Cedry Wielkie (Gross Zünder, ca I 450, height $50 \mathrm{~cm}$ ) and Kmiecin (Fürstenau, I 420-1 440, life-size) in the delta area of the Vistula river. It substantially postdates the typical works of Beautiful Madonnas. The difference is around two generations. The crucifix from Osice (Wossitz)

44 Waszak, "Snycerskie krucyfiksy," I: I $85-394$ (cat. no. 5); id., "Snycerskie krucyfiksy," 2: illus. 9, I 0 .

45 Waszak, "Snycerskie krucyfiksy," I : 486, 487 (cat. no 74); Joanna Będkowska, "Matka Boska Bolesna i św. Jan Ewangelista - średniowieczne figury z domniemanej grupy Ukrzyżowania z belki tęczowej w kościele Świętych Janów w Toruniu," Rocznik Toruński 37 (20 I o): 4I; Gwido Chmarzyński, "Sztuka w Toruniu. Zarys dziejów," in Dzieje Torunia: praca zbiorowa z okazji 7oo-lecia miasta, ed. Kazimierz Tymieniecki. (Toruń: staraniem Towarzystwa Miłośników Historji w Poznaniu: nakładem Zarządu Miejskiego w Toruniu, I933), 500, 50 I; Clasen, Die mittelalterliche Bildhauerkunst, I: I 8 I, 352 (cat. no. 595); Jerzy Domasłowski and Lilianna Krantz-Domasłowska, Kościót świętego Jakuba w Toruniu (Toruń: Towarzystwo Naukowe w Toruniu, 200 I), 68, 83.

46 Waszak, "Snycerskie krucyfiksy," I: 358, (cat. no. 50); Clasen Die mittelalterliche Bildhauerkunst, I: I64, I66, 356 (cat. no. 633). 
was repainted and was of a very small size. It shows an apparent degree of simplification when compared to the previous works pointed out by Clasen. Particularly simplified is very short perizoma and anatomy. The probably thick repainting softened and blurred its stylistic features. It is noteworthy that there is a great amount of even much later sculpted Madonnas holding the infant Jesus which invoke the Beautiful Madonnas style. They refer to the type which was in its original and absolute form created around the year 1400.

Especially the smaller or peripheral Gothic woodcarved crucifixes in little, parish churches represent various levels of simplification of the silhouette of the sculpted figure of the crucified Christ as well as artistic points of view of the perizoma with its drapery. The approaches to anatomical fidelity and its reduction differ. At the same time anatomical and stylistic transformations lead to a creation of a less complicated and less sophisticated sculpted in wood statue. Some researchers probably perceive the form of such sculptures as oversimplified. Infrequently, but it happens that such aesthetic views may be described as partially erroneous. Such crucifixes could be made for the general public. They might be intentionally created in a form that was easier to understand and more affordable. These figures at the same time have retained Gothic features and have been for many centuries suited for devotional or liturgical use. A few of the crucifixes were created nearly at the break of epochs or in a late phase of local Gothic which was coming to an end. Dating them before the Thirteen Years' War is probable. Although a few of them are supposed to be sculpted in a peripheral workshop or incorporated some folk-art features all of them were of a good or even very good aesthetic and artistic quality.

The state of conservation of the unpublished crucifixes was various. All of them were repainted, but none of them completely lost its polychromy nor was painted over in monochrome. The last way of treatment of Gothic crucifixes occurred frequently in the i 9 th century. Especially the one from Rychliki (Reichenbach) and the larger crucifix from Lidzbark Warmiński (Heilsberg) had damages, large losses of paint layers, probable activity of woodworms or even, in the second case, parts which might be unoriginal, replaced ones. Unappealing appearance of a work of art might lead to its aesthetical rejection and removing it from a church or even destroying it. Actually, it ought to be the other way round. The sculptures created in a distant past must be carefully restored and exhibited in the museums or should fulfil their cult and liturgical functions in sacral places. 


\section{CONCLUSION}

The sculpted crucifixes are an essential issue for the researchers, especially art historians and mediaevalists. Thanks to the fact, that they are numerously preserved or known from illustrations or mentioned in sources or academic literature they became up to now the symbols of lands and places, parts of the former territory of the Teutonic Order State in Prussia. Crucifixes although all of them are Gothic look differently in every epoch because of their damages, conservations, state of conservation. What is more, they were usually painted over a few times. In only the last few years the appearance of the crucifixes has dynamically changed. There were a lot of restoration works. Many of church interiors where the crucifixes are on display and are being venerated changed. Similar is with changing arrangements of museum exhibitions showing Gothic art. In this way, by scholarly works and conservation works the picture of the Prussian woodcarved Gothic crucifixes is being once again rewritten in the memory and consciousness of the researchers, the faithful and the art viewers. In this context it is to mention also fiction concerning the literary views on the crucifixes.

The previously not known pictures will help to enliven the discussion on the subject of Gothic crucifixes and woodcarved sculpture in the territory of the former Teutonic Order State. The archival photographs contribute to better knowledge of artistic output of a distant past. 


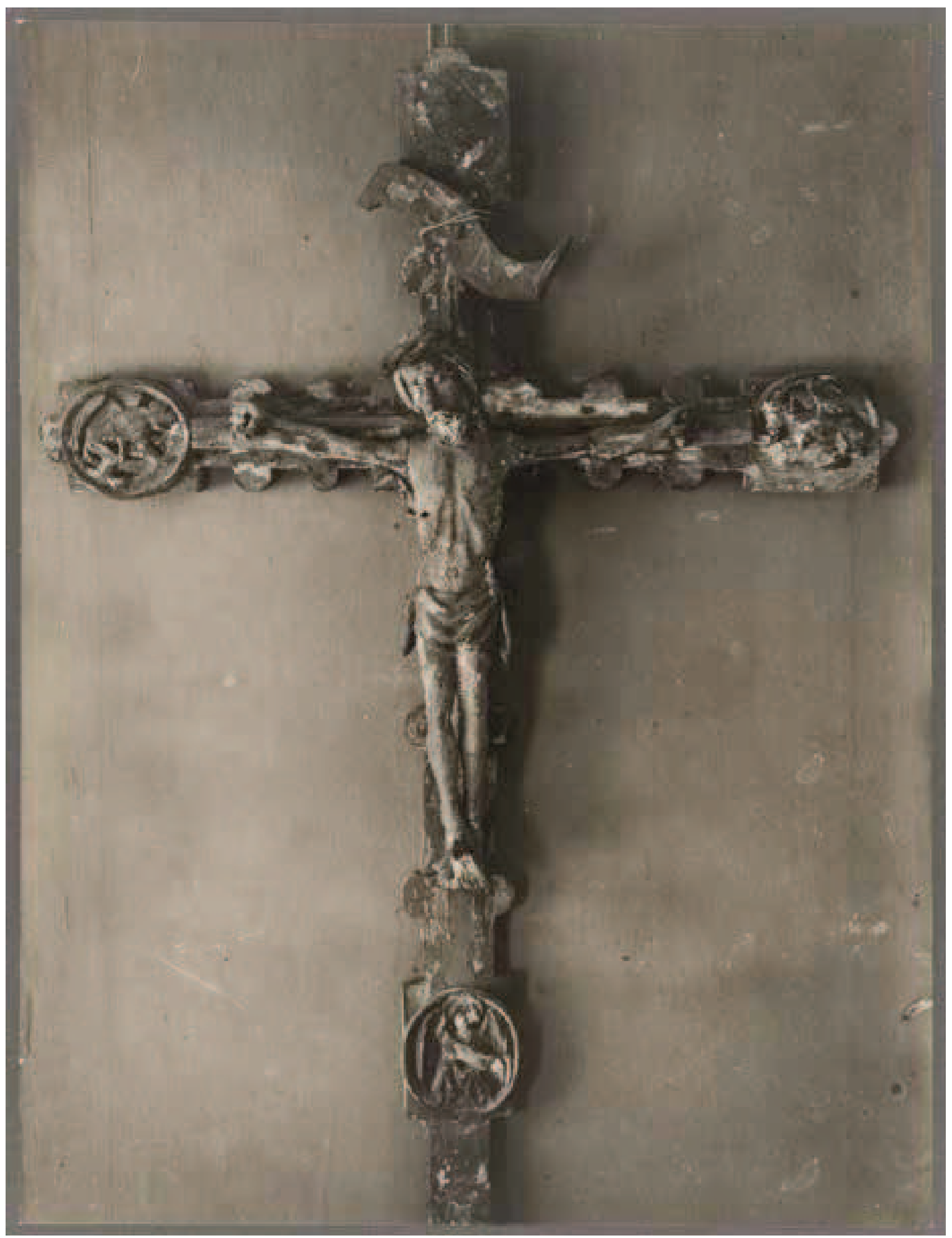

Ill. i: Rychliki (Reichenbach), crucifix, I 430-I 450, Herder Institute, Marburg, Bildarchiv, Sammlung Clasen, no. 97700. 


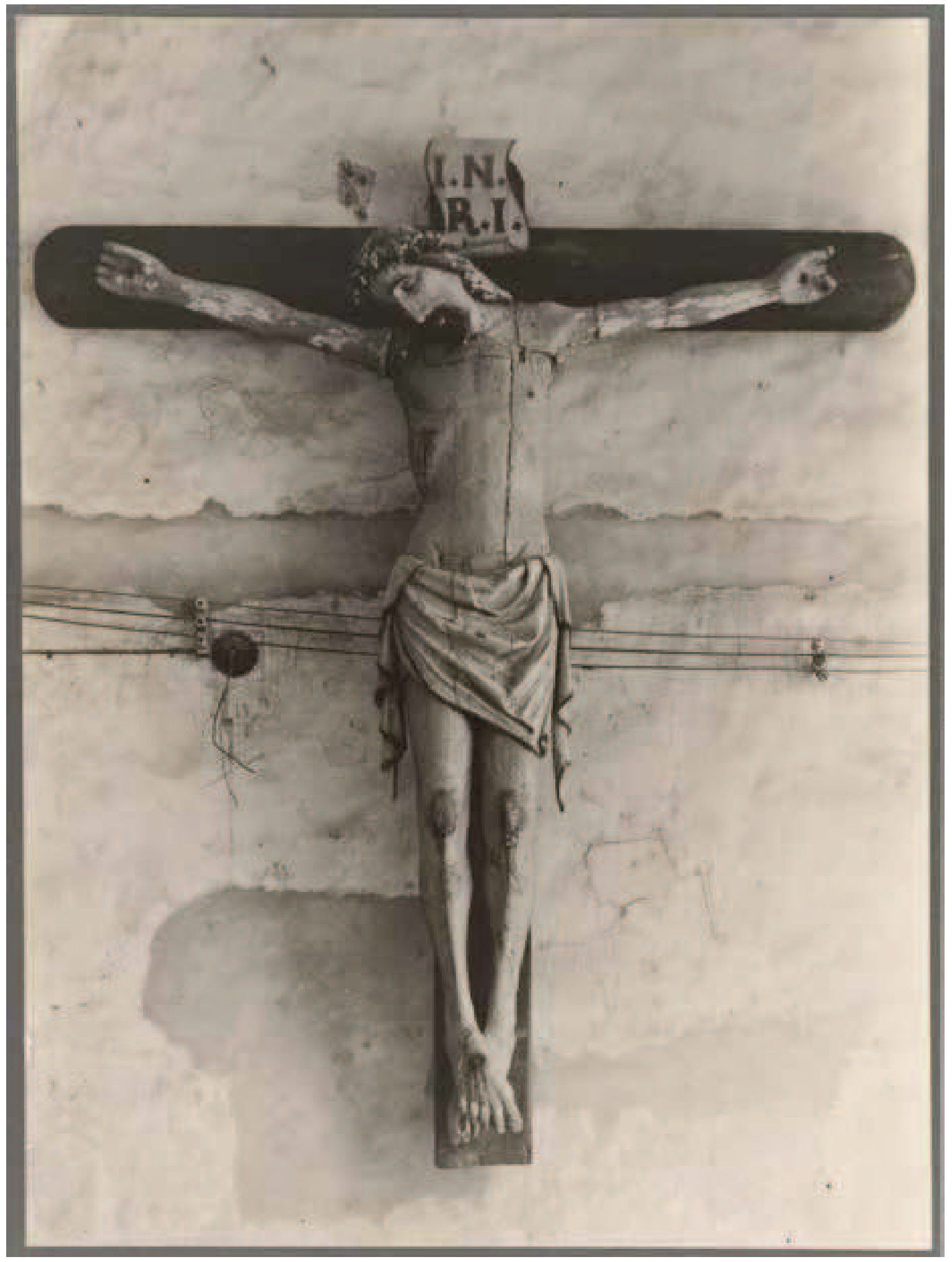

Ill. 2: LidZbark WARMińsKi (HeIlsberg), parish church?, later castle museum, crucifix, ca I450, Herder Institute, Marburg, Bildarchiv, Sammlung Clasen, no. 96932. 


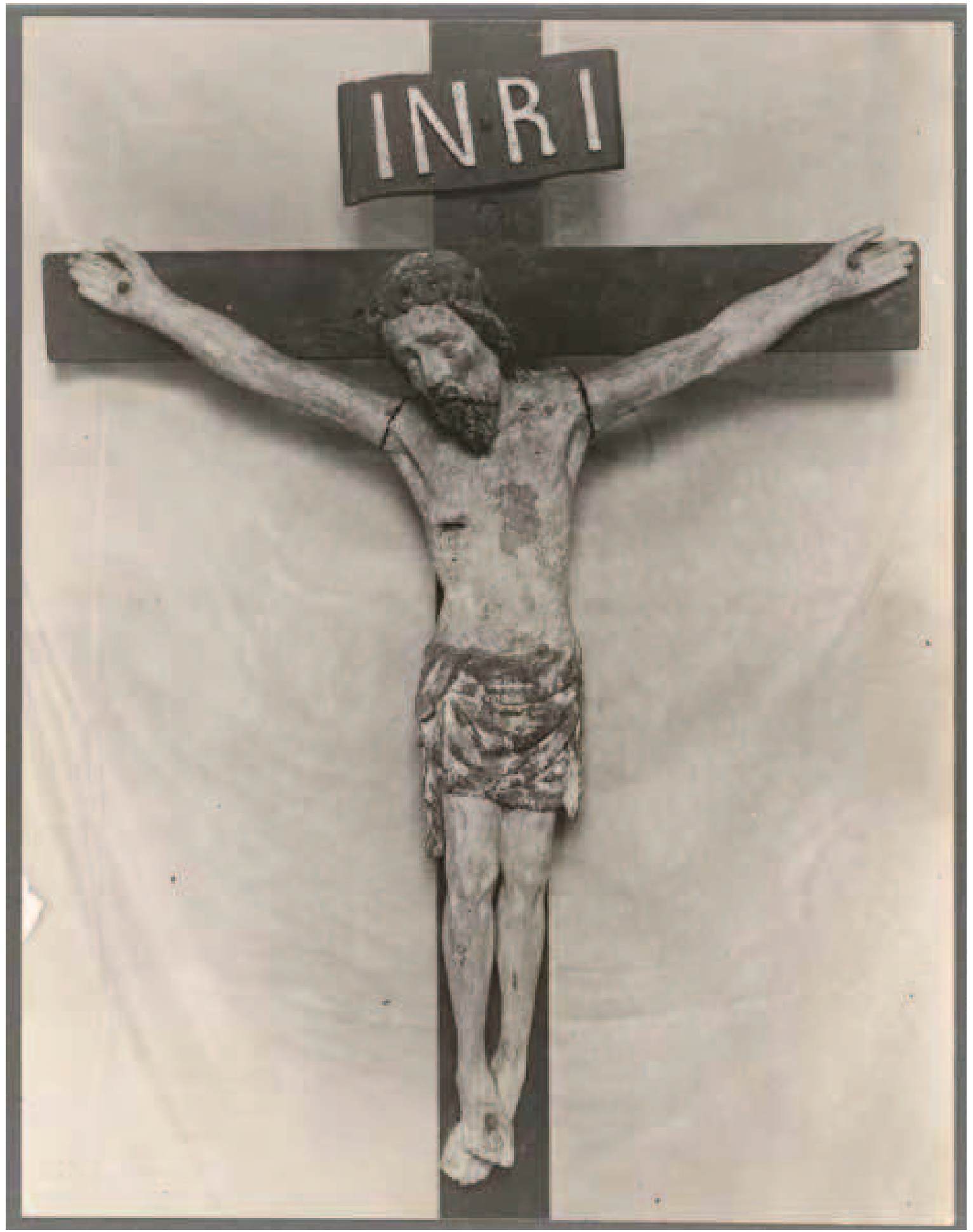

Ill. 3: Lidzbark Warmiński (Heilsberg), castle museum, crucifix, ca i 450, Herder Institute, Marburg, Bildarchiv, Sammlung Clasen, no. 96933. 


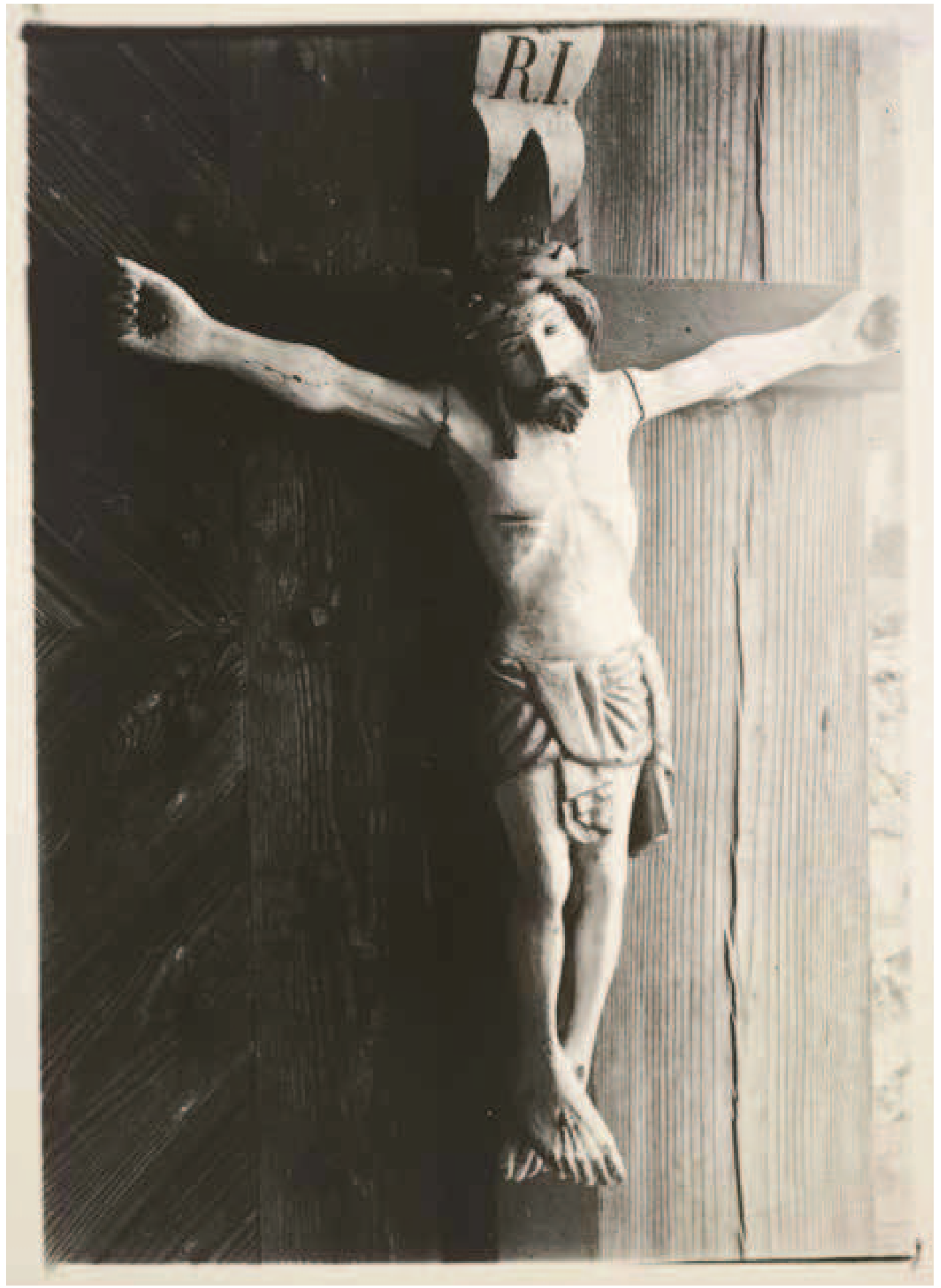

Ill. 4: MiŁoradz (Mielenz), smaller crucifix, ca I450, Herder Institute, Marburg, Bildarchiv, Sammlung Clasen, no. 97140. 


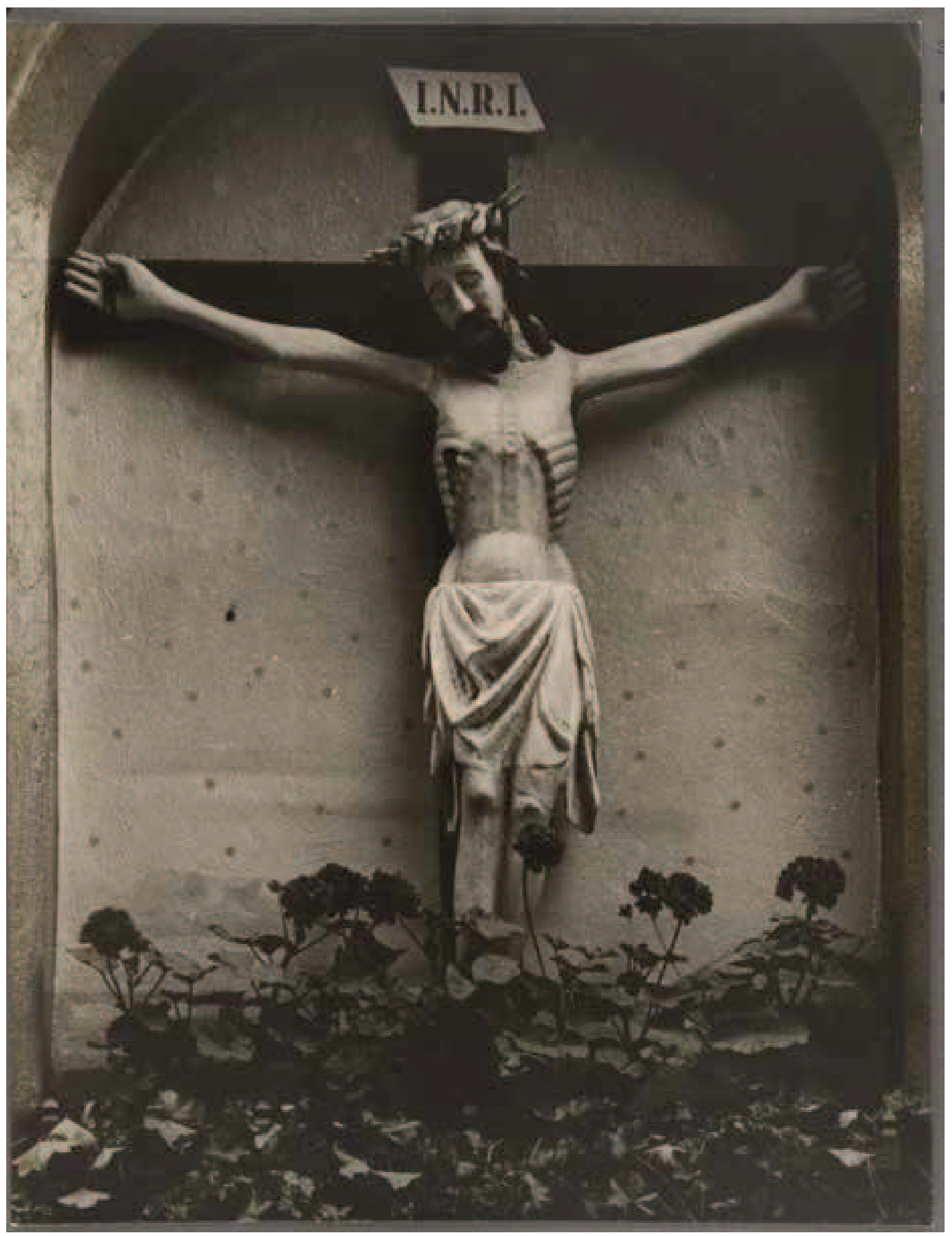

Ill. 5: Toruń (ThorN), above the St Jacob's hospital's entrance, 4 Szpitalna St., crucifix, I 400-I 425 , Herder Institute, Marburg, Bildarchiv, Sammlung Clasen, no. 97400. 


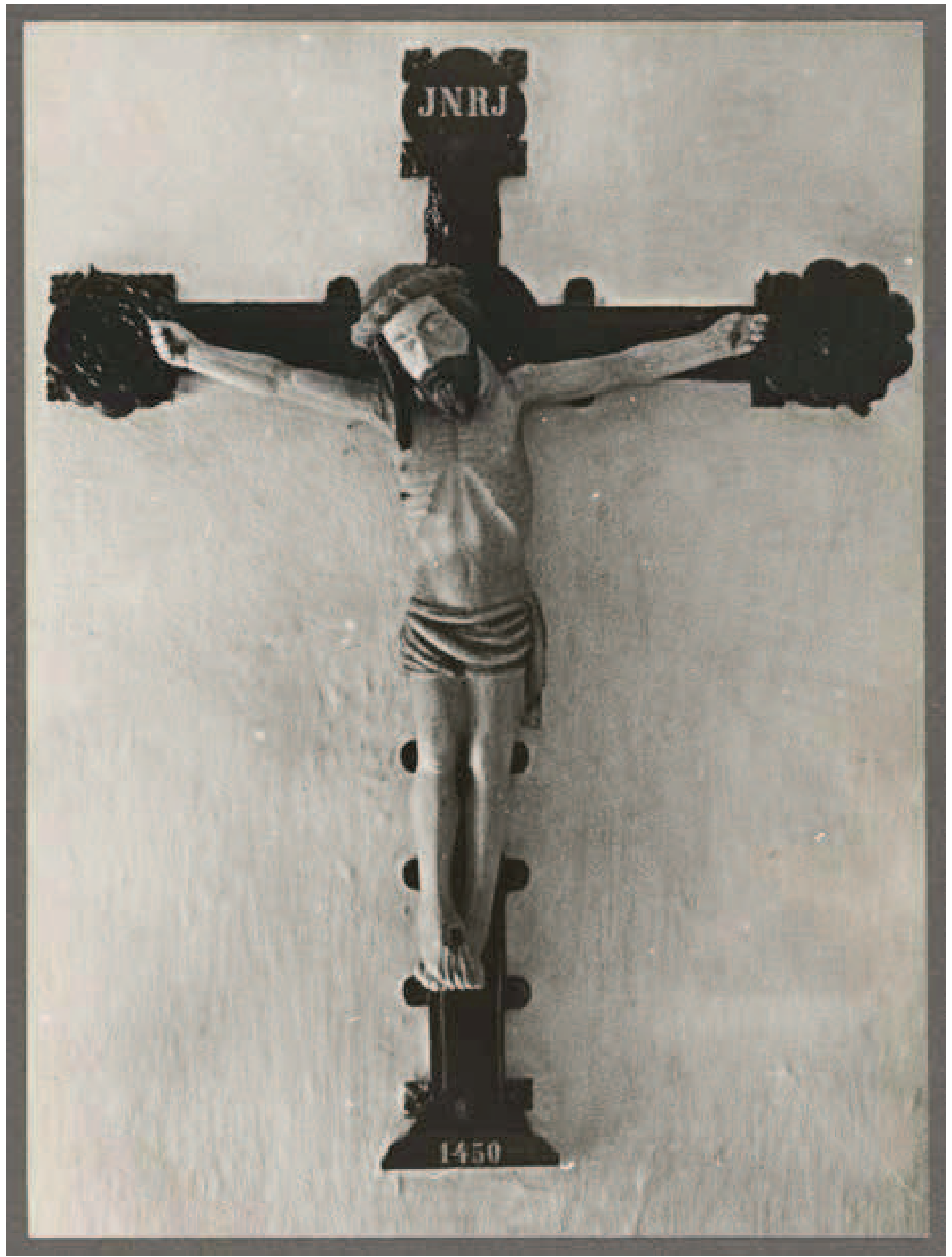

Ill. 6: Osice (Wossitz), crucifix, ca I450, Herder Institute, Marburg, Bildarchiv, Sammlung Clasen, no. 96958. 


\section{PRIMARY SOURCES:}

Gdańsk. Biblioteka Gdańska Polskiej Akademii Nauk, Ms. 488 (Schlieff Valentin, Der S. Marien Pfarrkirchen in Dantzig inwendiger Abriss beschrieben von Gregorio Frischen [...] Anno I 73 I. abgeschrieben und hin wieder verbessert und vermehret, Gdańsk).

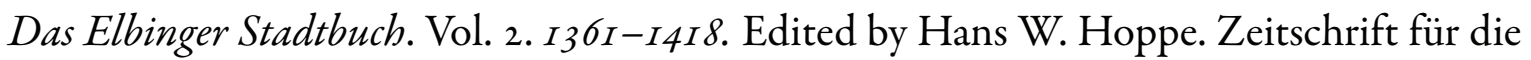
Geschichte und Altertumskunde Ermlands 5. Münster: Historischer Verein für Ermland, i 986.

Liber Mortuorum Monasterii Pelplinensis ordinis-cisterciensis. Edited by Wojciech Kętrzyński. In Monumenta Poloniae Historica / Pomniki dziejowe Polski. Vol. 4, edited by Lwowska Komisya Historycznej Akademii Umiejętności, 56-I 24. Lwów: Druk. Zakład Narodowy im. Ossolińskich, i 884.

\section{SECONDARY SOURCES:}

Af Ugglas, Carl R. "Sverige - Danzig eller Sverige - Köln - eller...?" Tidskrift för Konstvetenskap 25 ( 1944): I 2-52.

Antoni, Michael. Dehio-Handbuch der Kunstdenkmäler West-und Ostpreußen: die ehemaligen Provinzen West-und Ostpreußen (Deutschordensland Preußen) mit Bütower und Lauenburger Land. München-Berlin: Deutscher Kunstverlag, I 993.

Będkowska, Joanna. "Matka Boska Bolesna i św. Jan Ewangelista - średniowieczne figury z domniemanej grupy Ukrzyżowania z belki tęczowej w kościele Świętych Janów w Toruniu." Rocznik Torunski 37 (2010): 37-67.

Białłowicz-Krygierowa, Zofia. Studia nad snycerstwem XIV wieku w Polsce. Vol I. Poczatki ślaskiej tradycji ottarza szafowego. Warszawa-Poznań: Państwowe Wydawnictwo Naukowe, I98 I.

Błażejewska, Anna. Rzeźba w Prusach Krzyżackich do potowy XIV wieku: źródta stylu. Toruń: Wydawnictwo Naukowe Uniwersytetu Mikołaja Kopernika, 20 I 2.

Chmarzyński, Gwido. “Sztuka w Toruniu. Zarys dziejów.” In Dzieje Torunia: praca zbiorowa $z$ okazji 7oo-lecia miasta, edited by Kazimierz Tymieniecki, 469-544. Toruń: Staraniem Tow. Miłośników Historji w Poznaniu / nakł. Zarządu Miejskiego w Toruniu, 1933.

Chrzanowski, Tadeusz, and Marian Kornecki. "Nieznane rzeźby gotyckie kręgu pomorskiego." Rocznik Historii Sztuki 8 ( 1 970): 303-326.

Ciecholewski, Roman. "Problematyka badawcza pomorskich Madonn szafkowych." Studia Pelplinskie 8 ( I 977): I 27-I 52.

Clasen, Karl Heinz. Die mittelalterliche Bildhauerkunst im Deutschordensland Preussen. Die Bildwerke bis zur Mitte des I5. Jahrhundert. Vol. I-2. Berlin: Deutscher Verein für Kunstwissenschaft, 1939.

Dehio, Georg, and Ernst Gall. Deutschordensland Preußen, Handbuch der deutschen Kunstdenkmäler, with Bernhard Schmid and Grete Tiemann. München-Berlin: Deutscher Kunstverlag, I 952. 
Dollinger, Philippe. Dzieje Hanzy: (XII-XVII wiek). Edited by Edmund Cieślak. Translated by Vera Soczewińska. Gdańsk: Wydawnictwo Morskie, I 975.

Domasłowski, Jerzy, and Lilianna Krantz-Domasłowska. Kościót świętego Jakuba w Toruniu. Toruń: Towarzystwo Naukowe w Toruniu, 200 I.

Glauert, Mario. “Kirchen, Klöster und Spitäler zwischen Marienwerder und Rosenberg im Mittelalter: Ein Beitrag zur Sakraltopographie und Prosopographie des Niederklerus im Deutschordensland Preußen." Beiträge zur Geschichte Westpreußens 20/2 I (2006): 9-I I I.

Kaczmarek, Romuald. "Neue Überlegungen zu den schlesischen Löwenmadonnen: ihr Ursprung und stilistisch-formale Parallelentwicklungen in der Steinplastik." In Madony na lvu a mékký styl třetí čturtiny I4. století: př́rpèvky z mezinárodního symposia [Arcidiecézni Muzeum Olomouc, Ig. bezen 2014], edited by Jana Hrbáčová and Pavol Černý, 33-44. Olomouc: Muzeum umění, 20 i 4.

Kammel, Frank Matthias. "Andachtsbild und Formvielfalt: Skulptur." In Mittelalter: Kunst und Kultur von der Spätantike bis zum I s. Jahrhundert, edited by Jutta Zander-Seidel, 277-289. Nürnberg: Germanisches Nationalmuseum, 2007.

Karling, Sten. Medeltida träskulptur i Estland. Stockholm: Kungl. Vitterhets Historie och Antikvitets Akademien, I 946.

Karlsson, Lennart. “Träskulpturen.” In Den gotiska konsten, Signums svenska konsthistoria. Vol. 4, edited by Jan-Erik Augustsson, I 98-28 5. Lund: Bokförlaget Signum, 996.

Katalog Zabytków Sztuki w Polsce. Seria nowa. Vol. 2. Województwo elbląskie, fasc. I, Braniewo, Frombork, Orneta i okolice: tekst, edited by Marian Arszyński, Marian Kutzner, Piotr Skubiszewski, and Ewa Struszyńska. Warszawa: Instytut Sztuki Polskiej Akademii Nauk, i 980.

Kubler, George, Studies in Ancient American and European Art: The Collected Essays of George Kubler, edited by Thomas F. Reese. New Haven-London: Yale University Press, I 985.

Kubler, George. The shape of time: remarks on the history of things. New Haven-London: Yale University Press, 2008.

Kutzner, Marian. "Sztuka a kolonizacja niemiecka na wschód od Odry." In Niemcy - Polska $w$ Średniowieczu: materiaty z konferencji naukowej zorganizowanej przez Instytut Historii UAM w dniach I4-I6 XI I983 roku, edited by Jerzy Strzelczyk, 337-353. Poznań: Uniwersytet im. Adama Mickiewicza, 1986.

Kutzner, Marian. "Ziemia pruska i charakterystyka jej sztuki w okresie średniowiecza." Teka Komisji Historii Sztuki i (2005): 28-46.

Lutz, Gerhard. "Das Kruzifix von Askeby und die altniederländische Skulptur." In "Nicht die Bibliothek, sondern das Auge": westeuropäische Skulptur und Malerei an der Wende zur Neuzeit; Beiträge zu Ehren von Hartmut Krohm, edited by Tobias Kunz, I I I - I I 9. Petersberg: Imhof, 2008.

Michalski, Sergiusz. Einführung in die Kunstgeschichte. Darmstadt: Wissenschaftliche Buchgesellschaft, 2016. 
Norberg, Rune. "Helga Lekamensbilden i Vadstena och triumfkrucifixet i Söderköping." Birgittastiftelsen ärsberättelse I ( 194 I): I-25.

Nordman, Carl Axel. "Eigenes und Fremdes in der mittelalterlichen Kunst Finnlands." In Aspekte zur Kunstgeschichte von Mittelalter und Neuzeit. Karl Heinz Clasen zum 75. Geburtstag, edited by Hans Müller and Gudrun Hahn, 223-249. Weimar: Böhlau, I 975 .

Nordman, Carl Axel. Medeltida skulptur i Finland. Helsinki: Finska fornminnesföreningen, 1964 .

Orłowicz, Mieczysław. Ilustrowany przewodnik po Mazurach Pruskich i Warmji, Polska Biblioteka Turystyczna. Vol. 6. Lwów-Warszawa: Książnica Polska Towarzystwa Nauczycieli Szkół Wyższych, I 923.

Raam, Villem. Gooti puuskultur Eestis. Tallinn: Kirjastus "Kunst”, I 976.

Radler, Gudrun. Die Schreinmadonna "vierge ouvrante": von den bernhardinischen Anfängen bis zur Frauenmystik im Deutschordensland; mit beschreibendem Katalog. Frankfurt/Main: Kunstgeschichtliches Institut der Johann Wolfgang Goethe-Universität, I 990.

Roszak, Stanisław. "Morze jako miejsce pamięci w edukacji." In Battyk jako miejsce pamięci $w$ edukacji historycznej, edited by Danuta Konieczka-Śliwińska, Małgorzata Machałek, and Stanisław Roszak, I I-2 I. Szczecin-Warszawa: Polskie Towarzystwo Historyczne, 2017.

Strauss, Gerhard. Freiplastik bis I45o im Gebiet des heutigen Ostpreußen westlich der Passarge: Studie zur Geschichte mittelalterlicher Kunst im Ordensland Preußen. Königsberg: Albertus-Universität, 1937.

Tångeberg, Peter. "Retables and winged altarpieces from the fourteenth century: Swedish altar decorations in their European context." In The altar and its environment: II50-I400, edited by Justin E. A. Kroesen and Victor Michael Schmidt, 223-240. Turnhout: Brepols, 2009.

Tångeberg, Peter. "Künstlerische Verbindungen Schwedens im Mittelalter. Eine Übersicht." In Niederländische Kunstexporte nach Nord-und Ostmitteleuropa vom 14. bis I6. Jahrhundert: Forschungen zu ibren Anfängen, zur Rolle höfischer Auftraggeber, der Künstler und ibrer Werkstattbetriebe, edited by Jiř́ Fajt and Markus Hörsch, 6 I-85. Ostfildern: Jan Thorbecke Verlag, 20 I 4.

Tångeberg, Peter. Das "Schöne Kruzifix" in Vadstena und Nussbaumbolzskulpturen aus dem Deutschordensland. Stockholm: Almqvist \& Wiksell International, I 993.

Tångeberg, Peter. Retabel und Altarschreine des 14. Jahrbunderts: schwedische Altarausstattungen in ibrem europäischen Kontext. Stockholm: Kungl. Vitterhets Historie och Antikvitets Akademien 2005.

Waszak, Przemysław. “Krucyfiks na Drzewie Życia z dominikańskiego kościoła św. Mikołaja w Toruniu - nowe spojrzenie." Sztuka i Kultura I (2013):9-36.

Waszak, Przemysław. "Krucyfiks mistyczny na Drzewie Życia w kościele św. Jakuba, pochodzący z kościoła dominikanów (św. Mikołaja) w Toruniu.” MA thesis, Nicolaus Copernicus University, 2006. 
Waszak, Przemysław. Krucyfiks z Kaplicy Jedenastu Tysięcy Dziewic w Bazylice Mariackiej $w$ Gdansku. Jego znaczenie i recepcja. Toruń: Wydawnictwo Naukowe Uniwersytetu Mikołaja Kopernika, 2016.

Waszak, Przemysław. "Rozwojowe ciągi formalno-ideowe w ramach konstrukcji czasu artystycznego George’a Kublera.” Sztuka i Kultura s (2017) [in print].

Waszak, Przemysław. "Snycerskie krucyfiksy na obszarze Państwa Krzyżackiego w XIV i pierwszej połowie XV wieku.” PhD Dissertation, Nicolaus Copernicus University, $20 \mathrm{I} 2$.

Ważny, Tomasz, “Analiza dendrochronologiczna rzeźby Chrystus Ukrzyżowany z kościoła w Miłoradzu (woj. pomorskie), Toruń, I 7.I I.2003" [typescript]. In Dokumentacja prac konserwatorskich i restauratorskich, Chrystus Ukrzyżowany (w Mitoradzu), edited by Andrzej Jarmiłko, unnumbered. Torun 2003. Sztum, Archiwum kościoła św. Anny. Wennigsted-Torgard, Susanne. "Kruzifixe des I 4. Jahrhunderts auf Lolland-Falster und in Nordjütland." In Figur und Raum: mittelalteriche Holzbildwerke im historischen und kunstgeographischen Kontext, edited by Uwe Albrecht and Jan von Bonsdorff, with Annette Henning, 70-80. Berlin: Dietrich Reimer, 1994.

Wentzel, Hans. Lübecker Plastik bis zur Mitte des I4. Jahrbunderts. Berlin: Deutscher Verein für Kunstwissenschaft, I 938.

Wentzel, Hans. Review of Die mittelalterliche Bildhauerkunst im Deutschordensland PreuBen. Die Bildwerke bis zur Mitte des Is. Jhdts, by Karl Heinz Clasen. Zeitschrift des Vereins für Lübeckische Geschichte und Altertumskunde 30, no. 2 (1940): 388-392.

Żuchowski, Tadeusz J. "Niezwykłe spotkania. O wspólnocie artystycznej basenu Morza Bałtyckiego." Materiaty Zachodniopomorskie n.s. I, Nr. 2 (2004): 55-64. 